\title{
DAMPAK PELAYANAN GOFOOD TERHADAP PENJUALAN UNIT USAHA MIKRO MAKANAN LOKAL MITRA GOFOOD DI KOTA BANDUNG
}

\author{
Salman Hafidz ${ }^{1}$ \\ Manajemen Industri Katering, Universitas Pendidikan Indonesia \\ salmanhafidz12@student.upi.edu \\ Caria Ningsih $^{2}$ \\ Manajemen Industri Katering, Universitas Pendidikan Indonesia \\ caria.ningsih@upi.edu \\ Ilham Fajri ${ }^{3}$ \\ Akademi Pariwisata NHI Bandung \\ ilham@akparnhi.ac.id
}

\begin{abstract}
At this time the digital world has entered all sectors of life, the tourism sector for example with the google maps application to show tourist locations, hotel booking applications, and online transportation applications and food delivery services. Gofood is one of the food delivery services found on the Gojek application. With the presence of Gofood tourists who are in tourist destinations or lodging, especially in the city of Bandung can easily order local specialties or popular culinary in the city of Bandung. The purpose of this study was to determine the effect of Gofood services on increasing sales from local Gofood partner micro food businesses in the city of Bandung. This study uses quantitative methods using simple linear regression analysis, F-test and t-test. The results showed that the Gofood service variable was positive and significant and had an effect of $42.4 \%$ on the sales of Gofood partner local micro food businesses in the city of Bandung, the remaining $57.6 \%$ was the influence of variables not examined such as product quality, price, marketing management, mix marketing, etc. Gofood partner capital conditions are relatively increased by accumulation, but for daily capital, especially weekends (Friday, Saturday, Sunday, and national holidays) constrained because the disbursement of sales on that day only distributed to partners on Monday and above 12 noon, preferably in accelerate the disbursement because it affects the daily capital turnover.
\end{abstract}

Keywords: Gofood, sales, microbusiness, local food

\begin{abstract}
ABSTRAK
Pada saat ini dunia digital sudah memasuki semua sektor kehidupan, sektor pariwisata misalnya dengan aplikasi google maps untuk menunjukan lokasi wisata, aplikasi pemesanan hotel, dan aplikasi transportasi online dan layanan pesan antar makanan. Gofood salah satu layanan pesan antar makanan yang terdapat pada aplikasi Gojek. Dengan adanya Gofood wisatawan yang berada di destinasi wisata atau penginapan khususnya di Kota Bandung dapat dengan mudah memesan makanan khas lokal atau
\end{abstract}


kuliner yang populer di Kota Bandung. Tujuan dari penelitian ini adalah untuk mengetahui pengaruh layanan Gofood terhadap peningkatan penjualan dari usaha mikro makanan lokal mitra Gofood di Kota Bandung. Penelitian ini menggunakan metode kuantitatif dengan menggunakan metode analisis regresi linier sederhana, Uji F dan Uji t. Hasil penelitian menunjukan bahwa variabel layanan Gofood positif dan signifikan serta berpengaruh sebesar $42,4 \%$ terhadap penjualan usaha mikro makanan lokal mitra Gofood di Kota Bandung, sisanya 57,6\% merupakan pengaruh variabel yang tidak diteliti seperti kualitas produk, harga, manajemen marketing, bauran pemasaran, dll. Kondisi permodalan mitra gofood relatif meningkat secara akumulasi tetapi untuk modal harian khususnya akhir pekan (jumat, sabtu, minggu, dan libur nasional) terkendala karena pencairan penjualan pada hari tersebut baru disalurkan kepada mitra pada hari senin dan di atas jam 12 siang, sebagai saran sebaiknya dipercepat pencairannya karena berpengaruh terhadap perputaran modal harian.

Kata Kunci: Gofood, penjualan, usaha mikro, makanan local

Received: January 3, 2021/Reviewed: May 21, 2021/ Published: July 25, 2021

\section{PENDAHULUAN}

Bisnis kuliner di Kota Bandung menjadi salah satu bisnis yang menjanjikan. Kondisi cuaca yang cenderung dingin membuat kuliner Bandung selalu dimintai. Gofood salah satu layanan pesan antar makanan yang terdapat pada aplikasi Gojek. Keberadaan Gofood sangat membantu wisatawan yang berada di destinasi wisata atau penginapan khususnya di Kota Bandung, karena mereka dapat dengan mudah memesan makanan khas lokal atau kuliner yang populer di Kota Bandung.

Menurut Winarta, K (dalam Rakhmawati, A. 2019) gaya hidup masyarakat saat ini yang 'hobi' memesan makanan merupakan salah satu yang melandasi penggunaan layanan Gofood yang semakin meningkat. Terutama dari sudut pengusaha kuliner, mereka menggunakan layanan Gofood untuk memudahkan memasarkan makanannya. Menurut Ningsih, C., \& Sudono, A. (2016) di era globalisasi pengusaha kuliner harus memanfaatkan teknologi terbarukan untuk memajukan pariwisata dan kulinernya, sehingga mampu bersaing di dalam maupun luar negeri.

Terdapat 795 usaha makanan yang terdaftar secara resmi (Dinas Kebudayaan dan Pariwisata Kota Bandung, 2018), hal ini menandakan bahwa usaha makanan banyak peminatnya, ditambah lagi dengan adanya perkembangan platform digital berbasis aplikasi. Aplikasi tersebut dapat memudahkan penjual dan pembeli yang dipisahkan dengan jarak dapat melakukan transaksi jual beli tanpa harus keluar rumah. Internet menjadi salah satu strategi dan memberi kesempatan kepada perusahaan besar dan kecil untuk menawarkan secara cepat dengan biaya murah, menanggapi produk dan pelayanan dengan kualitas tinggi sesuai dengan kebutuhan konsumen. Internet membuat wajah baru untuk komunikasi interaktif antara konsumen, penjual, dan rekan bisnis lainnya, sehingga berkembanglah bisnis e-commerce (C Ningsih \& YJ Choi, 2018). Hal ini memungkinkan bahwa perusahaan mampu berinteraksi dan bekerja sama secara terus menerus dalam pengembangan produk, pemasaran, pengiriman, pelayanan, dan dukungan teknik.

Salah satu aplikasi yang menyediakan layanan tersebut yaitu Gojek dengan fitur layanan Gofoodnya. Gofood bekerja seperti layanan pesan antar di sebuah restoran, hanya dengan menggunakan smartphone yang sudah terpasang aplikasi Gojek konsumen bisa 
memesan makanan dari restoran maupun pengusaha makanan mikro, kecil, dan menengah (UMKM) bahkan pedagang kaki lima yang sudah menjadi mitra dari Gofood.

Bagi pengusaha mikro, kecil, menengah dan kaki lima adanya layanan Gofood menjadi suatu kemajuan bagi usahanya karena mereka tidak harus menyiapkan anggaran untuk layanan pesan antar karena semuanya sudah diakomodir oleh pihak Gojek. Gojek menyebut rekan bisnis dari pengusaha kuliner yang mendaftar menyebutnya sebagai mitra. Perlu diketahui sebagian masyarakat Indonesia lebih senang membeli makanan dari restoran waralaba cepat saji menggunakan aplikasi karena tersedianya promo potongan harga dan promo khusus dari restoran waralaba tersebut yang juga bisa dinikmati melalui layanan Gofood, sehingga harga makanan pun bisa hampir sama seperti makanan di pedagang mikro, kecil, menengah dan kaki lima, menurut Dwi Ayuningtyas (dalam CNBC Indonesia 2019). Restoran waralaba ternama di Indonesia yaitu KFC mendapat kenaikan sebesar 13,89\% melalui aplikasi Gofood pada tahun 2018. Jumlah transaksi makanan dan minuman yang dipesan lewat Go-Food mencapai 16,7 juta porsi/tahun atau sebanyak 45.753 porsi/hari akumulasi dari semua outlet di Indonesia, di mana lebih dari setengahnya (10 juta porsi) merupakan paket ayam. Sedangkan untuk membeli makanan dari pengusaha mikro, kecil, menengah dan kaki lima yang masih konvensional dan/atau belum terafiliasi dengan sistem online maka masyarakat Indonesia khususnya di Kota Bandung diharuskan datang secara langsung ke tempatnya, maka dari itu mereka bergabung menjadi mitra Gofood dengan tujuan untuk meningkatkan penjualan agar dapat bersaing dalam industri kuliner.

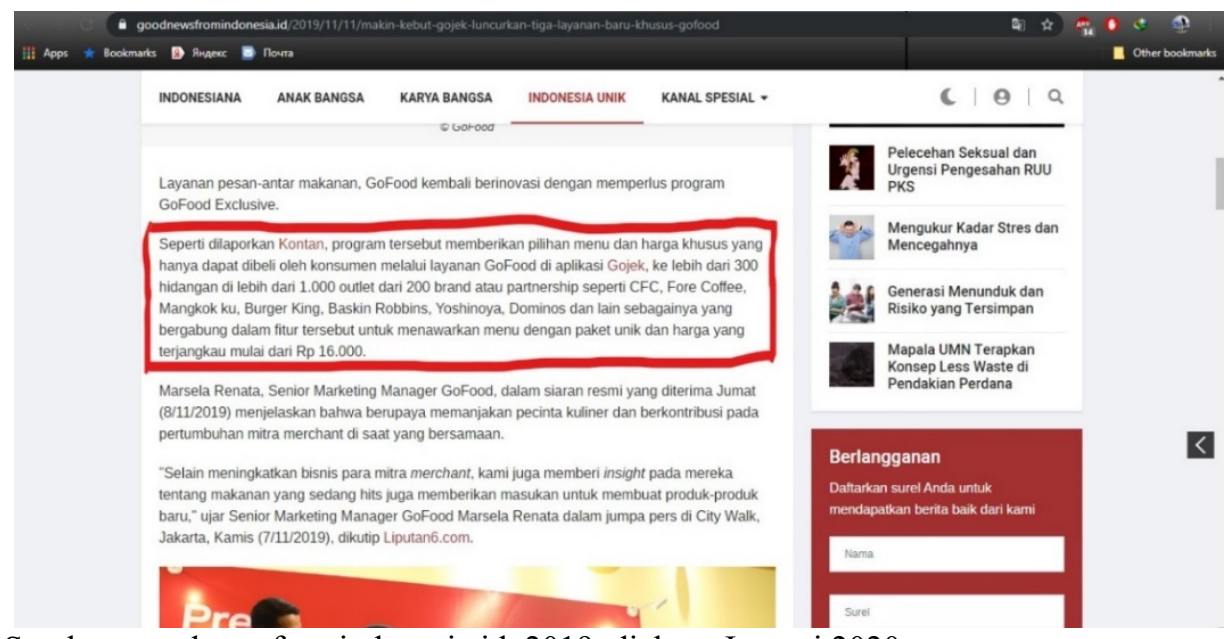

Sumber: goodnewsfromindonesia.id, 2019, diakses Januari 2020

Gambar 1. Bukti masalah

Pada gambar 1 di atas menjelaskan Brand seperti CFC, Fore Coffee, Burgerking, Yoshinoya dan Domino's Pizza yang notabenenya adalah perusahaan waralaba Fastfood untuk menarik pelanggan bekerjasama dengan program dari Gofood yang menawarkan menu dengan harga mulai dari Rp. 16.000. Dengan harga tersebut bisa mengambil pangsa pasar dari usaha mikro, kecil, menengah dan kakilima.

Selain bukti masalah di atas penulis melakukan survey kepada 30 mitra Gofood yaitu: Padang Madang, Suki Seleraku, Pentolata, Keepsmile Bubble Tea, Dimsum Dimsam, Bebek Komar, Kebab Turki Babarafi Gegerkalong, Kebab melted, BooDimsum, Nasi Goreng Kang Sharung, Seblak B186, Soto Ayam Unpas, RM Padang Retha Jaya, Bangbou Dimsum, Warung Ayam Berontak, Ayam Bakar Arab Madinah, Ayam Geprek Komar, Rumah Makan Rajo Bungsu, Willy’s Fried Chicken, Eatbang, 
Dheyzachipz, Suket Susu Ketan, Jasuke DT, Sora Frozen Food, Demir Turkish, Bakso Kopdar, Teewoo Jus Tebu Alami, Kaza Bubble Tea, Onion Shuhlin, Ayam-Ayaman @ Corner. Usaha mereka bergabung menjadi mitra Gofood kurun waktu 2 minggu s/d 2 tahun, menurut 30 pemilik dengan bergabung menjadi mitra Gofood rata rata ada 10-15 driver Gojek yang mengambil pesanan/hari, dan penjualan pun meningkat rata-rata $20 \%$ perhari. Pendapatan perhari tidak selalu berbanding lurus dengan peningkatan penjualan dikarenakan adanya menu yang di berikan harga promo. (Pra-survei, Januari 2020, Data Diolah).

Menurut Mahmoedin (2010) pelayanan adalah suatu aktivitas atau serangkaian aktivitas yang bersifat tidak kasat mata yang terjadi sebagai akibat adanya interaksi antara konsumen dengan karyawan atau hal - hal lain yang disediakan oleh perusahaan pemberi pelayanan yang dimaksud untuk memecahkan permasalahan konsumen/pelanggan.

Berdasarkan latar belakang yang telah dikemukakan di atas, penelitian ini bermaksud untuk mengetahui Pengaruh Layanan Gofood Terhadap Peningkatan Penjualan dari Usaha Mikro Makanan Lokal Mitra Gofood di Kota Bandung. Adapun rinciannya sebagai berikut:

1. Untuk mengtahui pelayanan yang diberikan Gofood dalam meningkatkan penjualan mitranya khususnya usaha mikro.

2. Untuk mengetahui penjualan dari usaha mikro makanan lokal mitra Gofood di Kota Bandung.

3. Untuk mengetahui pengaruh layanan Gofood terhadap peningkatan penjualan pada mitra Gofood usaha mikro makanan lokal di Kota Bandung

\section{METODOLOGI}

Metode penelitian yang digunakan dalam penelitian ini adalah metode kuantitatif yang bertujuan untuk merekam data sebanyak-banyaknya dari populasi yang luas. Penelitian ini dilakukan dalam kurun waktu kurang dari satu tahun, metode penelitian yang digunakan adalah cross sectional method. Menurut Noor. J (2012) Cross sectional method merupakan studi yang dilakukan dengan data hanya sekali dikumpulkan selama periode harian, mingguan, atau bulanan dalam rangka menjawab pertanyaan dari penelitian.

Instrumen penelitian yang digunakan dalam penelitian ini berupa kuesiner dengan menggunakan skala semantic differential. Sugiyono, P. D. (2013) menyatakan bahwa skala semantic differential yaitu skala untuk mengukur sikap, tersusun dalam satu garis kontinum di mana jawaban yang sangat positif terletak di bagian kanan garis, dan jawaban yang sangat negatif terletak di bagian kiri garis, atau sebaliknya. Pada penelitian ini terdapat 5 tingkatan skor, semakin besar skor, semakin positif, dan semakin rendah skor, semakin negatif. Peneliti menggunakan jenis instrumen kuesioner dengan pemberian skor sebagai berikut:

\begin{tabular}{|l|l|l|l|l|l|l|}
\hline Tidak Berpengaruh & 1 & 2 & 3 & 4 & 5 & Sangat Berpengaruh \\
\hline
\end{tabular}

\section{HASIL DAN PEMBAHASAN}

Gojek merupakan salah satu perusahaan hasil karya anak bangsa yang bergerak di bidang e-commerce. Perusahaan ini berkembang sangat cepat di kota-kota besar di Indonesia salah satunya di Kota Bandung. Gojek memiliki beberapa layanan dalam aplikasinya salah satunya layanan Gofood. Dengan aplikasi Gojek diharapkan dapat memudahkan masyarakat dan membantu memenuhi kebutuhan dalam aktivitas sehari-hari dimanapun berada. 
Gojek didirikan oleh Nadiem Makarim, warga negara Indonesia. Ide mendirikan Gojek muncul dari pengalaman pribadi menggunaan transportasi ojek sebagai angkutan umum untuk berangkat kerja. Nadiem melihat sebagian besar waktu yang dihabiskan oleh pengemudi ojek hanya mangkal untuk menunggu penumpang. Selain itu, Nadiem melihat ketersediaan jenis transportasi ini tidak sebanyak transportasi umum lainnya sehigga seringkali cukup sulit untuk dicari. Nadiem menginginkan ojek yang selalu ada setiap di butuhkan, dari pengamatan inilah Nadiem melihat adanya peluang untuk membuat sebuah layanan yang dapat menghubungkan penumpang dengan pengemudi ojek.

Perusahaan ini resmi didirikan pada tanggal 13 Oktober 2010 di jakarta, dengan 20 orang pengemudi ojek yang terdaftar. Pada saat itu, Gojek masih mengandalkan Call Center untuk menghubungkan penumpang dengan pengemudi ojek. Pada akhirnya Gojek resmi meluncurkan aplikasi bebasis Android dan iOS untuk menggantikan sistem pemesanan menggunakan Call Center pada tanggal 7 Januari 2015.

Tabel 1. Hasil Uji Regresi Linier Sederhana

\begin{tabular}{|c|c|c|c|c|}
\hline \multicolumn{5}{|c|}{ Model Summary } \\
\hline Model & $\mathrm{R}$ & $\begin{array}{c}\mathrm{R} \\
\text { Square }\end{array}$ & $\begin{array}{c}\text { Adjusted R } \\
\text { Square }\end{array}$ & $\begin{array}{l}\text { Std. Error } \\
\text { of the } \\
\text { Estimate }\end{array}$ \\
\hline 1 & $.651^{\mathrm{a}}$ & .424 & .417 & 3.905 \\
\hline
\end{tabular}

Tabel 1 di atas menjelaskan besarnya nilai korelasi hubungan (R) yaitu sebesar 0,651. Dari data tersebut diperoleh koefisien determinasi (R Square) sebesar 0,424 yang mengandung pengertian bahwa pengaruh variabel $X$ (Layanan Gofood) terhadap variabel Y (Penjualan) adalah sebesar 42,4\%.

Tabel 2. Hasil Uji Regresi Sederhana

\begin{tabular}{|c|c|c|c|c|c|c|}
\hline \multicolumn{7}{|c|}{ ANOVA $^{\mathrm{a}}$} \\
\hline \multicolumn{2}{|c|}{ Model } & $\begin{array}{l}\text { Sum of } \\
\text { Squares }\end{array}$ & Df & $\begin{array}{c}\text { Mean } \\
\text { Square }\end{array}$ & $\mathrm{F}$ & Sig. \\
\hline \multirow[t]{3}{*}{1} & $\begin{array}{l}\text { Regress } \\
\text { ion }\end{array}$ & 919.081 & 1 & 919.081 & $\begin{array}{r}60.26 \\
9\end{array}$ & $.000^{\mathrm{b}}$ \\
\hline & Residua & 1250.479 & 82 & 15.250 & & \\
\hline & Total & 2169.560 & 83 & & & \\
\hline
\end{tabular}

a. Dependent Variable: Penjualan

b. Predictors: (Constant), Layanan Gofood

Sumber: Data Diolah Peneliti, 2020.

Tabel 2 menjelaskan bahawa nilai $\mathrm{F}$ hitung $=60,269$ dengan tingkat signifikansi sebesar $0,000<0,05$, maka ada pengaruh variabel Layanan Gofood $(X)$ terhadap variaber Penjualan (Y).

Tabel 3. Hasil Uji Regresi Sederhana

\begin{tabular}{|c|c|c|c|c|}
\hline \multicolumn{5}{|c|}{ Coefficients $^{\mathbf{a}}$} \\
\hline & $\begin{array}{l}\text { Unstandardized } \\
\text { Coefficients }\end{array}$ & $\begin{array}{c}\text { Standardiz } \\
\text { ed } \\
\text { Coefficien } \\
\text { ts }\end{array}$ & & \\
\hline Model & B Std. Error & Beta & $\mathrm{t}$ & Sig. \\
\hline
\end{tabular}




\begin{tabular}{|c|c|c|c|c|c|c|}
\hline 1 & (Constant) & -1.827 & 3.371 & & -.542 & .589 \\
\hline & $\begin{array}{l}\text { Layanan } \\
\text { Gofood }\end{array}$ & .922 & .119 & .651 & 7.763 & .000 \\
\hline
\end{tabular}

Berdasarkan tabel 3 menunjukkan nilai constanta (a) sebesar -1,827, sedangkan nilai (b) sebesar 0,922 , sehingga persamaan regresinya dapat di tulis:

$\mathrm{Y}=\mathrm{a}+\mathrm{bX}$

$\mathrm{Y}=-1,827+0,922$

Maka, koefisien regresi X sebesar 0.922 menyatakan bahwa setiap penambahan 1 satuan nilai penjualan, maka nilai partisipasi bertambah sebesar 0.922 .

\subsection{Hasil Uji Korelasi}

Tabel 4. Uji Korelasi

\begin{tabular}{|c|c|c|c|}
\hline \multicolumn{4}{|c|}{ Correlations } \\
\hline & & $\begin{array}{c}\text { Layanan } \\
\text { Gofood }\end{array}$ & Penjualan \\
\hline \multirow{4}{*}{$\begin{array}{l}\text { Layanan } \\
\text { Gofood }\end{array}$} & Pearson & 1 & $.651^{* *}$ \\
\hline & Correlation & & \\
\hline & Sig. (2-tailed) & & .000 \\
\hline & $\mathrm{N}$ & 84 & 84 \\
\hline \multirow[t]{3}{*}{ Penjualan } & $\begin{array}{l}\text { Pearson } \\
\text { Correlation }\end{array}$ & $.651^{* *}$ & 1 \\
\hline & Sig. (2-tailed) & .000 & \\
\hline & $\mathrm{N}$ & 84 & 84 \\
\hline
\end{tabular}

Sumber: Data Diolah Peneliti, 2020.

Berdasarkan tabel 4 menunjukan bahwa nila signifikansi $0.00<0,05$, maka dua variabel ini berkorelasi. Nilai korelasi pada tabel 4.10 sebesar 0,651 , maka antara variabel Layanan Gofood (X) dengan variabel Penjualan (Y) mempunyai hubungan kuat positif.

\subsection{Hasil Uji Partial (Uji t)}

Pengujian hipotesis secara parsial dimaksudkan untuk mengetahui ada atau tidaknya pengaruh variabel bebas secara parsial terhadap variabel terikat. Hasil hipotesis dalam pengujian ini adalah sebagai berikut:

Jika t hitung $>\mathrm{t}$ tabel, maka Ho ditolak dan $\mathrm{H}_{\mathrm{a}}$ diterima Jika $\mathrm{t}$ hitung $<\mathrm{t}$ tabel, maka Ho diterima dan $\mathrm{H}_{\mathrm{a}}$ ditolak

Tabel 5. Hasil Uji Partial

\begin{tabular}{ll|l|l}
\multicolumn{2}{l|}{ Model } & & \\
\hline 1 & (Constant) & -.542 & .589 \\
\cline { 2 - 4 } & Layanan Gofood & 7.763 & .000 \\
\hline \multicolumn{2}{c}{ Sumber: Data Diolah Peneliti, 2020.}
\end{tabular}


Berdasarkan tabel 5 hasil Uji t di atas untuk mengetahui besarnya pengaruh masing-masing variabel independen secara parsial terhadap variabel dependen adalah sebagai berikut: Pengaruh Variabel Layanan Gofood (X) terhadap Penjualan(Y).

Nilai t hitung untuk layanan Gofood sebesar 7,763 sedangkan nilai t tabel sebesar 1,988. Maka dapat diketahui thitung 7,763 > 1,988 dan nilai signifikan 0,000 lebih kecil dari 0,05 . Sehingga hipotesis yang berbunyi terdapat pengaruh layanan Gofood terhadap penjualan diterima (Ha diterima dan Ho ditolak), artinya secara parsial terdapat pengaruh yang signifikan antara layanan Gofood terhadap penjualan.

\subsection{Hasil Uji Simultan (Uji F)}

Uji simultan F menunjukkan apakah semua variabel independen atau bebas yang dimasukkan dalam model mempunyai pengaruh secara bersama-sama terhadap variabel dependen atau terikat. Uji statistik $\mathrm{F}$ digunakan untuk memenuhi semua pengaruh variabel independen yang diuji pada tingkat signifikan 5\%. Hasil hipotesis dalam pengujian ini adalah sebagai berikut:

F hitung $>$ F tabel maka keputusan menolak hipotesis nol (Ho) dan menerima hipotesis alternatif $\left(\mathrm{H}_{\mathrm{a}}\right)$

$\mathrm{F}$ hitung $<\mathrm{F}$ tabel maka keputusan menerima hipotesis nol (Ho) dan menolak hipotesis alternatif $\left(\mathrm{H}_{\mathrm{a}}\right)$

Tabel 6. Hasil Uji Signifikan Simultan

\begin{tabular}{|c|c|c|c|c|c|c|}
\hline \multicolumn{7}{|c|}{ ANOVA $^{\mathrm{a}}$} \\
\hline \multicolumn{2}{|c|}{ Model } & $\begin{array}{l}\text { Sum of } \\
\text { Squares }\end{array}$ & Df & $\begin{array}{c}\text { Mean } \\
\text { Square }\end{array}$ & $\mathrm{F}$ & Sig. \\
\hline \multirow[t]{3}{*}{1} & $\begin{array}{l}\text { Regressi } \\
\text { on }\end{array}$ & 919.081 & 1 & 919.081 & $\begin{array}{r}60.26 \\
9\end{array}$ & $.000^{\mathrm{b}}$ \\
\hline & Residual & 1250.479 & 82 & 15.250 & & \\
\hline & Total & 2169.560 & 83 & & & \\
\hline
\end{tabular}

a. Dependent Variable: Penjualan

b. Predictors: (Constant), Layanan Gofood

Sumber: Data Diolah Peneliti, 2020.

Berdasarkan tabel 6 nilai $\mathrm{F}$ hitung yang diperoleh 60,269 sedangkan nilai $\mathrm{F}$ tabel sebesar 3,95 maka dapat diketahui nilai $\mathrm{F}$ hitung 60,269 > F tabel 3,90 dengan tingkat siginifikan $0,000<0,05$. Dengan kata lain dapat dikatakan Ho ditolak dan Ha diterima. Maka variabel layanan Gofood berpengaruh signifikan terhadap variabel penjualan.

\subsection{Pembahasan Hasil Penelitian}

Berdasarkan hasil analisis yang telah diuraikan di atas diperoleh hasil bahwa variabel (X) layanan Gofood berpengaruh signifikan terhadap variabel (Y) penjualan usaha mikro makanan lokal di Kota Bandung. Hal tersebut ditunjukkan dari hasil nilai t hitung untuk layanan Gofood sebesar 7,763 sedangkan nilai t tabel sebesar 1,988. Maka dapat diketahui t hitung 7,763 $>1,988$ dan nilai signifikan $0,000<0,05$. Sehingga hipotesis yang berbunyi terdapat pengaruh layanan Gofood terhadap penjualan diterima (Ha diterima dan Ho ditolak), artinya secara parsial terdapat pengaruh yang signifikan antara layanan Gofood terhadap penjualan.

Layanan Gofood secara simultan berpengaruh signifikan terhadap penjualan usaha mikro makanan lokal mitra Gofood di Kota Bandung. Hal ini dibuktikan dengan nilai $\mathrm{F}$ hitung yang diperoleh 60,269 sedangkan nilai $\mathrm{F}$ tabel sebesar 3,95 maka dapat diketahui nilai $\mathrm{F}$ hitung $60,269>\mathrm{F}$ tabel 3,90 dengan tingkat siginifikan $0,000<0,05$. 
Dengan kata lain dapat dikatakan bahwa variabel layanan Gofood berpengaruh signifikan terhadap variabel penjualan. Sedangkan nilai $\mathrm{R}_{\text {square }}$ sebesar $42,4 \%$, maka koefisien determinasi dari layanan Gofood (X) dan penjualan (Y) sebesar 42,4\%. Sisanya dipengaruhi faktor-faktor lain diluar variabel layanan Gofood, seperti kualitas produk, harga, manajemen marketing, bauran pemasaran, dll.

Selain itu juga diperoleh persamaan regresi $\mathrm{Y}=-1,827+0,922 \mathrm{X}$. Persamaan tersebut sesuai dengan rumus regresi linier sederhana yaitu $\mathrm{Y}=\mathrm{a}+\mathrm{bX}$, dimana $\mathrm{Y}$ merupakan lambang dari variabel terikat, a konstanta, $b$ koefisien regresi untuk variabel bebas (X). sehingga dapat disimpulkan dari hasil uji t, terdapat pengaruh antara variabel Y terhadap Variabel X, dengan kata lain menerima Ha yaitu: Ada Pengaruh Layanan Gofood Terhadap Penjualan Usaha Mikro Makanan Lokal mitra Gofood di Kota Bandung dan menolak $\mathrm{H}_{\mathrm{o}}$, yaitu Tidak Pengaruh Layanan Gofood Terhadap Penjualan Usaha Mikro Makanan Lokal Mitra Gofood di Kota Bandung. Konstanta sebesar -1,827 artinya jika layanan Gofood (X) nilainya adalah 0, maka penjualan (Y) nilainya yaitu sebesar 1,827. Koefisien regresi variabel pejualan sebesar 0,922 artinya jika harga mengalami kenaikan 1 satuan nilai, maka penjualan (Y) akan mengalami peningkatan sebesar 0,922. Variabel Layanan Gofood (X) dengan variabel Penjualan (Y) mempunyai hubungan kuat positif karena memiliki nilai korelasi sebesar 0,651.

Berdasarkan uraian diatas, maka dapat disimpulkan bahwa layanan Gofood mempengaruhi penjualan usaha mikro makanan lokal mitra Gofood di Kota Bandung.

Hal ini menunjukan bahwa lanyanan Gofood berhasil memecahkan masalah usaha mikro dalam layanan pesan antar, seperti yang di kemukakan oleh Mahmoedin, H. As. (2010) bahwa pelayanan yaitu suatu akvitas yang bersifat tidak kasat mata yang terjadi sebagai akibat adanya interaksi antara konsumen dengan karyawan atau hal-hal lain yang disediakan oleh perusahaan pemberi pelayanan yang dimaksud untuk memecahkan permasalahan konsumen/pelanggan. Pelayanan dalam layanan pesan antar yang berhasil dipecahkan oleh Gofood yaitu ada 7 indikator menurut Dinitzen, H. B. (2010) yaitu: Delivery Flexibility, Delivery Accuracy, Stock Service, After-Sales Service, Order Management, Marketing and Communication, E-Information. Meskipun demikian masih ada beberapa catatan yang harus di benahi.

\section{SIMPULAN}

Gofood memberikan fasilitas kepada mitranya seperti sistem pembayaran non-tunai yaitu Gopay, Sistem operasional usaha yaitu aplikasi GoBiz, dan mitra Gofood berhak untuk bergabung dalam Komunitas Partner Gofood.

Variabel layanan Gofood skor tertinggi pada indikator Delivery Accuracy yaitu mengenai pesanan yang dikembalikan oleh pembeli dengan skor 4,57 ini menunjukan bahwa pesanan yang di kembalikan oleh pembeli hampir tidak ada, hal tersebut bisa terjadi karena di dukung oleh Indikator Order Management yaitu sistem pengoperasian pemesanan dari Gofood sangat mudah untuk di operasikan terbukti degan skor 4,54. Sedangkan rata-rata terendah terdapat pada indikator E-Information dengan skor 3,20 ini menunjukan bahwa memperbarui informasi terkait menu oleh mitra masih terbilang jarang. Variabel penjualan skor tertinggi pada pada indikator Kondisi dan Kemampuan Penjual yaitu mengenai volume penjualan setelah bergabung di Gofood dengan rata-rata 3,98 ini menunjukan bahwa peningkatan volume penjualan mitra Gofood makanan lokal di kota bandung cukup signifikan. Sedangkan rata-rata terendah terdapat pada indikator Kondisi Organisasi Penjual dengan rata-rata skor 1,67 ini menunjukan bahwa jumlah pegawai relatif sedikit atau tidak memiliki pegawai. 
Variabel layanan Gofood berpengaruh kuat positif dan signifikan secara parsial dan simultan terhadap peningkatan penjualan sebesar $42,4 \%$. Sisanya $57,6 \%$ dijelaskan atau dipengaruhi oleh variabel lain yang tidak di teliti oleh peneliti seperti kualitas produk, harga, manajemen marketing, bauran pemasaran, dll.

\section{Rekomendasi}

Berikut ini merupakan rekomendasi yang ditujukan kepada pihak Gofood:

Pihak Gofood lebih aktif lagi untuk mengundang dan mengajak seluruh mitra Gofood untuk bergabung kedalam Komunitas Partner Gofood karena masih ada mitra gofood yang belum mendapatkan seluruh fasilitas yang dijanjikan oleh pihak gofood yaitu belum bergabung kedalam Komuntas Partner Gofood, padahal di sana terdapat banyak informasi terkait kemitraan, seperti seminar yang di selenggarakan untuk mitra Gofood, promosi yang sedang berlangsung, konsultasi terkait masalah yang di alami mitra, dan tempat bertukar pikiran dan cerita sesama mitra Gofood.

Kondisi permodalan mitra gofood relatif meningkat secara akumulasi tetapi untuk modal harian khususnya akhir pekan (jumat, sabtu, minggu, dan libur nasional) terkendala karena pencairan penjualan pada hari tersebut baru di salurkan kepada mitra pada hari senin dan di atas jam 12 siang, sebaiknya di percepat pencairannya karena berpengaruh terhadap perputaran modal harian.

Pihak gofood sebaiknya mengurangi biaya layanan sebesar $20 \%$ karena cukup memberatkan mitra, khususnya yang perpartisipasi pada event promo yang di selenggarakan oleh Gofood, karena pada promo tersebut mitra juga harus memberikan harga diskon sesuai event yang sedang berlangsung, dan untuk yang tidak ikut promo bisa mengurangi harga jualnya untuk mendapatkan harga jual yang lebih kompetitif. Saat penelitian ini berlangsung terdapat pandemi Covid-19 sehingga dengan pemotongan biaya layanan sebesar $20 \%$ tersebut semakin memberatkan mitra usaha mikro, dan ada beberapa usaha tutup untuk sementara.

Sediakan fitur persediaan yang siap di jual, sehingga untuk memudahkan pembeli untuk mengcek ketersediaan produk dahulu sebelum memesan dan mitra pun tidak harus membatalkan pesanan apabila menu yang di pesan pelanggan sudah habis.

Sediakan fitur chat dari mitra Gofood ke pelanggan dan dapat digunakan pada saat pesanan masuk dan pasca pesanan selesai, sebagai bentuk after sales service.

Iklan dan Promosi untuk UMKM khususnya usaha mikro baiknya di tempatkan pada halaman dan urutan pertama pada aplikasi dan terpisah dengan promosi merek restoran besar, sebagai bentuk dan cara untuk menigkatkan penjualan produk dari UMKM khususnya usaha mikro.

Saran untuk peneliti selanjutnya diharapkan penelitian berikutnya tidak sebatas variabel layanan gofood dan penjualan saja, akan tetapi juga menambahkan variabel lain dan sektor usaha lain pada penelitian selanjutnya.

\section{DAFTAR PUSTAKA}

Abdullah, Thamrin dan Francis Tantri. 2012. Manajemen Pemasaran. Depok: PT Raja Grafindo Persada

Amelia, R., \& LP3M, P. U. 2019. Pengaruh Aplikasi Gofood Terhadap Peningkatan Penjualan Mochitalk Plaza Medan Fair.

Arikunto. 2010. Prosedur Penelitian: Suatu Pendekatan Praktek. Jakarta: Rineka Cipta. 
C Ningsih \& YJ Choi, 2018, An Effect of Internet Penetration on Income Inequality in Southeast Asian Countries, Calgary: International Telecommunications Society (ITS)

Baraban, R. S., \& Durocher, J. F. 2010. Successful restaurant design. New York: Van Nostrand Reinhold.

Benedictus, P. K. (2019). Pengaruh Service Quality dan Online Servicescape Terhadap Keputusan Pembelian Melalui Brand Image (Studi kasus pada Mahasiswa FISIP Undip Pengguna Jasa Transportasi Online Go-Jek) (Doctoral dissertation, Faculty of Social and Political Sciences).

Bungin, B. 2011. Metode Penelitian Kuantitatif edisi kedua. Jakarta: Kencana.

Ningsih, C., \& Sudono, A. (2016), The Competitiveness of Indonesia Tourism Industry in Facing ASEAN Economic Community. Heritage, Culture and Society: Research agenda and best practices in the hospitality and tourism industry

Chon, K., \& Maier, T. 2010. Welcome to hospitality: an introduction.(3rdedn). Cengage Learning, Delmar, USA.

Dantes, Nyoman. 2012. Metode Penelitian. Yogyakarta. Andi Offset.

Dadan Eka Permana. 2018. Perkembangan Kuliner di Era Digitalisasi. Jakarta: www.liputan6.com/lifestyle/read/3683767/perkembangan-kuliner-di-eradigitalisasi.

Dinas Kebudayaan dan Pariwisata Kota Bandung, 2018

Dinitzen, H. B. 2010. Organisational theory. Hans Reitzels Forlag.

Dwi Ayuningtyas. 2019. Gofood Grabfood Bikin Penjulan KFC Naik 13,89\%. CNBC Indonesia.

Ghozali, I. 2006. Aplikasi analisis multivariate dengan program SPSS.

Good News from Indonesia, 2019, link: www.goodnewsfromindonesia.id, 2019, diakses Januari 2020

Hidayatullah, S., Waris, A., Permata, Y., Adrian, T., Sarwinda, N., Lestari, F. W., \& Eka, A. A. G. 2018, September. Eksistensi Transportasi Online (Go Food) Terhadap Omzet Bisnis Kuliner Di Kota Malang. In Seminar Nasional Sistem Informasi (SENASIF) (Vol. 2, No. 1, pp. 1423-1429).

Indraswari, A., \& Kusuma, H. 2018. Analisa Pemanfaatan Aplikasi Go-Food Bagi Pendapatan Pemilik Usaha Rumah Makan di Kelurahan Sawojajar Kota Malang. Jurnal Ilmu Ekonomi JIE, 2(1), 63-73.

Iriani, T. Y., \& Endang Rostiana, S. E. 2018. Analisis Dampak Layanan Go-Food Terhadap Omzet Penjualan Rumah Makan Di Kota Bandung (Doctoral dissertation, Perpustakaan Fakultas Ekonomi dan Bisnis Unpas Bandung).

Kristanto, H. (2015). Keadilan Organisasional, Komitmen Organisasional, dan Kinerja Karyawan. Jurnal Manajemen dan Kewirausahaan. 17(1).86-98.

Lexy, J. M. DMA 2019. Metodologi Penelitian Kualitatif (Edisi Revisi). PT. Remaja Rosda Karya.

Liputan6. 2019. Kemajuan Teknologi Jadi Peluang Bagi Industri Kuliner Lokal. Jakarta: www.liputan6.com/bisnis/read/3991657/kemajuan-teknologi-jadi-peluang-bagiindustri-kuliner-lokal.

Mahmoedin, H. As, 2010. Melacak Kredit Bermasalah. Cetakan Pertama. Jakarta: Pustaka Sinar Harapan

Meyers, Koen. 2009. Pengertian Pariwisata, Jakarta: UNESCO Office.

M. Narafin, 2006. Penganggaran, Edisi 3, Penerbit Salemba Empat, Jakarta.

McLeod Pearson. 2008. Sistem Informasi Manajemen. Salemba. Jakarta. 
MUHAMMAD FANIAWAN, A. S. R. I. A. N. S. Y. A. H. 2016. ANALISIS FAKTORFAKTOR YANG MEMPENGARUHI PENERAPAN INFORMASI AKUNTANSI PADA UMKM PEMPEK (KAJIAN PADA UMKM PEMPEK DI KAWASAN PASAR 26 ILIR KOTA PALEMBANG) (Doctoral dissertation, Politeknik Negeri Sriwijaya).

Noor, J.2012.Metodologi Penelitian. Jakarta. Kencana Prenada Media Group.

Nurbayti, N. 2019. Tren Pengguna Aplikasi Go-Food di Era Digital. Jurnal Komunikasi, Masyarakat dan Keamanan, 1(1).

NSS, R. L. P., \& Rahoyo, R. 2019. DAMPAK BISNIS KULINER MELALUI GO FOOD BAGI PERTUMBUHAN EKONOMI DI KOTA SEMARANG. Jurnal Dinamika Sosial Budaya, 20(2), 120-133.

Pieniak, Z., Verbeke, W., Vanhonacker, F., Guerrero, L., \& Hersleth, M. 2009. Association between Traditional Food Consumption and Motives for Food Choice in Six European Countries. Appetite Journal, 53, 101-108.

PT. Aplikasi Karya Anak Bangsa. 2019. Gojek tentang kami. Jakarta: www.gojek.com/about/

PT. Aplikasi Karya Anak Bangsa. 2019. Gabung gofood. Jakarta: www.gojek.com/gofood/join/

PT. Aplikasi Karya Anak Bangsa. 2019. Struktur Organisasi.Gojek Cabang Bandung. Bandung.

Purnomo, S. H., \& Lee, Y. H. 2013. E-learning adoption in the banking workplace in Indonesia: an empirical study. Information Development, 29(2), 138-153.

Rakhmawati, A. 2019. ANALISIS PENGARUH PENGGUNAAN APLIKASI GOFOOD TERHADAP PENDAPATAN RUMAH MAKAN.

Sugiama, A Gima S, 2011, Developing Model of Agri-trourism based on Tourism Quality Components that Influencee Tourist Satisfaction and Loyalty (Case of Service in Bandung), Proceeding-International Seminar on Scientific Issues and Trends (ISSIT)-2011, BSI Univesity, Yogyakarta.

Sugiyono, 2009, Metode Penelitian Kuantitatif, Kualitatif dan R\&D, Bandung: Alfabeta.

Sugiyono, 2011. Metode Penelitian Kuantitatif, Kualitatif dan R\&D. Bandung: Alfabeta.

Sugiyono, 2012. Metode Penelitian Kuantitatif, Kualitatif dan R\&D. Bandung: Alfabeta.

Sugiyono, P. D. 2013. Statistik untuk Penelitian. Bandung: CV. Alfabeta.

Sugiyono, 2014. Metode Penelitian Kuantitatif, Kualitatif dan R\&D. Bandung:CV. Alfabeta.

Sugiyono, 2017. Metode Penelitian Kuantitatif, Kualitatif, dan R\&D. Bandung: Alfabeta, $\mathrm{CV}$.

Sujarweni, V. W. 2014. Metodologi penelitian: Lengkap, praktis, dan mudah dipahami. Yogyakarta: Pustakabarupress.

Sukmana, E. 2005, April. Digitalisasi Pustaka. In Makalah pada Seminar "Peran Pustakawan pada era digital (Vol. 16).

Swastha, Basu, 2008. Manajemen Penjualan, BPFE, Yogyakarta.

Ulam, A. P. 2019. PENGARUH HARGA TERHADAP KEPUTUSAN PEMBELIAN KONSUMEN GO-FOOD DI KOTA BANDUNG (Doctoral dissertation, Universitas Pendidikan Indonesia).

Umar, H. 2012. Penelitian Kuantitatif (Langkah demi langkah). Pelatihan Metodologi Penelitian Kopertis III.

Undang-undang Nomor. 5 Tahun 1984 tentang Industri.

Undang-undang Nomor. 10 tahun 2009 tentang Kepariwisataan. 
Undang-undang Nomor 20 Tahun 2008 temtang UMKM.

Varmaat, Shelly Cashman, 2007. Discovering Computers: Menjelajah Dunia Komputer Fundamental Edisi 3, Jakarta: Salemba Infotek.

Winardi, J. 2005, Manajemen Perubahan (The Management of Change), Cetakan Ke-1, Jakarta, Prenada Media.

Winarta, K. 2015. Ojek Online yang Menjadi Pesaing Gojek. Retrieved Oktober, 10, 2015.

Wong, Jony, 2010. Internet Marketing for Beginners, Elex Media Komputindo, Jakarta. 